\title{
The Effect of Paternalistic Leadership on Employee Innovative Behavior in Indonesian Startup Companies: The Mediating Role of Psychological Empowerment
}

\author{
Tri Handayani ${ }^{*}$, Yanki Hartijasti ${ }^{2}$ \\ ${ }^{1,2}$ Universitas Indonesia, Depok, Indonesia \\ "Corresponding author. Email: trihandayani.82@ui.ac.id
}

\begin{abstract}
Companies can become more innovative by leveraging the ability of employees to innovate. It is operationalized through innovative behavior and highly influenced by the leader. Empowerment is considered capable of mediating the effect of leadership on innovative behavior. Employees with innovative behaviors can be fast and accurately respond to customers, develop new ideas, and create new products. This study aims to examine effect of paternalistic leadership (benevolent, moral, and authoritarian) on innovative behavior, the effect of psychological empowerment on innovative behavior; and the effect of paternalistic leadership's on employees' innovative behavior mediated by psychological empowerment. The data were collected from 119 employees of several startup companies in Indonesia. Researchers used Hayes Process method to assess the proposed hypotheses and evaluate the mediating role. The findings suggest that psychological empowerment mediates the effect of benevolent and authoritarian leadership on innovative behavior. However, this study indicates that psychological empowerment does not mediate moral leadership and innovative behavior. This study provides recommendations to leaders and the organization's management in formulating HR management practices to improve company's innovation performance through leadership style by creating a positive work environment that affects employee innovative behavior through psychological empowerment.
\end{abstract}

Keywords: paternalistic leadership, benevolent leadership, moral leadership, authoritarian leadership, psychological empowerment, innovative behavior, startup.

\section{INTRODUCTION}

A company's success depends on innovation and the adoption of new technologies that have a critical influence on environmental dynamics and external competition [1]. Innovation is one of the essential factors for a company because it can ensure business growth and become a strong pillar to drive the company's success $[2,3,4,5]$.

Companies can become more innovative by leveraging employees' ability to innovate. Employees can help improve business performance through their ability to generate ideas, solutions, and use them as a foundation for new and better products, services, and work processes [6]. Several researchers described individual innovation like individual personality [7], outcome [8], and behavior $[9,10]$.

Innovative behavior is individual creativity, which is the starting point for innovation [11]. Employee work behavior, including innovative behavior, one of which is greatly influenced by the leader $[12,13,14,15,16]$. However, several researchers believe that an essential factor in explaining the relationship between leadership and innovative behavior is psychological empowerment $[17,18]$. If empowerment applies in the work environment, employees will have confidence in achieving independent and successful tasks in a meaningful way and impacting their work $[19,20]$.

However, a leader cannot choose their style at will and select the things that can make them successful because it is very dependent on the cultural context [21]. The leadership style in several countries in the Asian region, such as Hongkong, Taiwan, Singapore, and Indonesia, influenced by the Chinese migrated and carried out the economic activities in that's countries. This leadership style identifies as paternalism or paternalistic leadership (benevolent, moral, authoritarian) [21].

Several studies have analyzed the effect of paternalistic leadership on innovative behavior mediating by psychological empowerment. If moral leaders give employees autonomy and independence, it will affect their work, and they feel empowered [22]. When benevolent leaders support employees and provide them with resources related to tasks, employees feel as if they are given strength [18, 23] and have a free environment to work [24]. Also, benevolent leaders encourage employees to exert their initiatives, provide suggestions for the development of departments and companies, and actively promote innovative behavior. But on the other hand, authoritarian leadership is considered to be able to 
prevent innovative behavior by ignoring innovative thinking and requiring a high level of employee compliance $[14,16,25]$. When authoritarian leaders start with strict rules and want employees to obey their instructions, employees feel less effective and less empowered [26].

However, a different paradigm emerged among researchers regarding the relationship between leadership, empowerment, and innovative behavior. Several researchers analyzed the relationship between paternalistic leadership and empowerment, but innovative behavior did not study as a result of empowerment [22, 27]. Similar to several studies examining leadership on innovative behavior, only a few assess the role of empowerment in the relationship between these factors [23, 28, 29].

Apart from the critical role of empowerment in influencing leadership and innovative behavior, less literature knows about these three variables' relationship dynamics.

Based on the previous studies, there is less literature about the role of empowerment mediation, which explains paternalistic leadership's effect on innovative behavior. Therefore, this study aims to examine the effect of paternalistic leadership (benevolent, moral, and authoritarian) on innovative behavior, the effect of psychological empowerment on innovative behavior; and the effect of paternalistic leadership's on employees' innovative behavior mediated by psychological empowerment.

This study conduct on employees at several startup companies in Indonesia. The startup is a technology-based company with high innovation competence. These companies have a strong need for small, continuous improvements and additions to their current product or service offerings, so addressing employees' innovative behavior is very important in this context. With this knowledge, startup leaders expect to manage their leadership style to impact employee empowerment, and influencing innovative employee behavior.

\section{Empowerment}

Empowerment can see as a psychological attribute, or psychological empowerment, which is a state of motivational cognition generated in an individual by an organizational environment that reflects the individual's personality [20]. Empowerment is an individual's perception or attitude towards work and its role in an organization [30]. Empowerment is a psychological aspect of how people gain more control over their lives, participate in democratic decision-making, and develop a critical awareness of their socio-political environment [31]. Empowerment is a cognitive state characterized by a perceived sense of control, competence, and internalization of goals [32] and increased intrinsic motivation in performing tasks [20].

Psychological empowerment describes into four cognitions: meaning, competence, self-determination, and impact $[19,20]$. Meaning is the value of work goals, assessed by individual ideals or standards, job roles, beliefs, and behavior. Competence, namely the individual's trust and mastery of their ability to carry out activities with the skills they have or the expectations of business-performance. Selfdetermination, namely individual feelings about choices in initiating, organizing actions, making decisions regarding work methods, steps, and efforts [19]. Impact, namely the extent to which individuals can influence strategic, administrative results in the workplace [33], the degree to which a person can influence strategic, management, and desired results at work [19]. Refers to Dedahanov's research [18], psychological empowerment is a mechanism that can explain the effect of paternalistic leadership on innovative behavior.

\section{Paternalistic Leadership}

Paternalistic leadership is a leadership style prevalent in Chinese business organizations and is similar to patriarchy. Paternalistic leadership is a "paternal" leadership style in which clear and strong authority combines with care, concern, and consideration for subordinates with moral elements $[21,34]$. Cheng's paternalistic leadership model in Taiwanese Chinese society contains a Confucian philosophy. This philosophy considers being the basic thinking that a paternalistic leadership model will fit into Indonesian culture [35].

Paternalistic leadership is categorized into three dimensions: benevolent, moral, and authoritarian [21]. Benevolent describe as leader behavior that shows individual concern for family welfare and employee needs. In addition to work-related problems, a benevolent leader shows concern for employees' personal and family problems, comfort, provides support when employees are underperforming, and supports employees when they have problems [34]. It causes employees to express gratitude, love, and do the same to the leader [36]. Therefore, based on the above discussed features of benevolent leaders, which influence all four dimensions of empowerment, researchers suggest the following hypothesis:

H1: Benevolent leadership has a positive effect on psychological empowerment.

Moral leadership describes a leader's behavior who shows superior personal virtues, self-discipline, and unselfishness [34]. A moral leader provides an example to his employees regarding integrity and responsibility to fulfill an individual's obligations, not taking advantage of others, and an exemplary attitude [18]. A moral leader shows integrity and focuses on collective good rather than personal interests; they are highly admired, respected, and considered ideal leaders [37]. These moral leaders exert their strength to be role models for their employees, building a more personal emotional bond between leaders and followers. Hence, researchers suggest the following hypothesis:

H2: Moral leadership has a positive effect on psychological empowerment. 
Authoritarian leadership describes the behavior of a leader who asserts absolute authority and control over subordinates and demands obedience from subordinates [34]. An authoritarian leader tends to determine what needs to be done, create a structure, promise rewards for compliance, issue rules, and threaten reprimands if subordinates do not comply [26]. Authoritarian leadership has personal control over most problems and employess [54], where the outcome is highly dependent on the leader [38]. Authority has controls and impacts organizational problems, reflecting the dimensions and impact of empowerment [39]. Thus, based on the discussions above, researchers believe that authoritarian leadership influences of empowerment, and researchers propose the following hypothesis:

H3: Authoritarian leadership has a negative effect on psychological empowerment.

\section{Innovative Behavior and Empowerment}

Innovative behavior is individual behavior in recognizing a problem, generating or adopting new ideas, processes, procedures, solutions, and products; introducing or promoting and building support; and implementing it into work and benefiting the performance of individuals, groups, or organizations [9, 12, 40, 41, 42]. Employees with innovative behavior can fast and appropriately respond to customers, propose new ideas, and create new products [43].

Empowered employees can survive despite barriers inside and outside the organization [20]. Employees who are empowered will provide new ideas for the company. Empowerment through autonomy enables employees to engage in 'trial and error' and find more efficient and effective ways of doing their jobs. Trial and error are vital requirements in the innovation process, so that work autonomy gives employees a way to try new ideas even when faced with failure [44]. Empowerment through work method autonomy can provide employees with space to experiment with alternative work procedures, methods, and innovations that they can propose at a later stage [45].

There is study proves that psychological empowerment is associated with innovative behavior [18]. Based on the discussion above, researchers conclude that empowerment is considered as one of the contributing factors to innovative behavior and researchers propose the following hypothesis:

H4: Psychological empowerment has a positive effect on innovative behavior.

\section{Mediating Role of Empowerment}

A number of previous study's proves that the relationship between leadership and employee innovative behavior is mediated by empowerment [18, 46]. When leaders devote their energies to taking care of employees, giving employees freedom and opportunities in their work [22], employees tend to feel empowered if given autonomy in doing their jobs. It makes employees more likely to create new ideas. This statement strengthens the research results that empowerment is the foundation for an innovative process [49]. There is study proves that meaning, competency, and impact are significant determinants of innovative behavior, while self-determination allows employees to be confident in exploring new opportunities [39].

On the contrary, when employees have to follow the leader's rules to do their job, they tend not to control what happens in the workplace [48]. As a result, employees are reluctant to seek or produce new technologies, methods, product ideas, and techniques [18]. Hence, we believe that paternalistic leadership influences employee innovative behavior through empowerment. Therefore, researchers propose that:

H5: Psychological empowerment mediates the effect of benevolent leadership on innovative behavior.

H6: Psychological empowerment mediates the effect of moral leadership on innovative behavior.

H7: Psychological empowerment mediates the effect of authoritarian leadership on innovative behavior.

\section{METHOD}

\subsection{Sample}

The respondents of this study are employees who work in startup companies in several regions in Indonesia. Startups characteristics are less than ten years old; they have innovative products, services and business models to develop by increasing employees and/or turnover and/or market places [50]. Startups are newly established businesses in the early stages of growth and rapidly increase business scale [51].

This study used a purposive sampling method in which respondent should be an employee who works in startup companies. The survey conduct using the Google Form application. Researchers sent research proposals through email to 21 startup companies in Sumatera region and 106 startup companies in Java region. Through this method, 69 respondents were collected from 7 startup companies.

Second stages, researchers distributed the survey link to several colleagues who work at startup companies through social media such as LinkedIn, WhatsApp, Facebook, and Instagram. Through this method, 57 respondents from 51 startups were collected.

A total of 126 employees participated in the survey, but 7 questionnaires not used because the type of company did not match the criteria of a startup.

Of the 119 respondents, 59.66 percent were male, and 40.34 percent were female. Concerning age, 41.18 percent were between 26 and 30 years, 36.97 percent were between 21 and 25 years, and 18.49 percent between 31 and 35 , and less than 2 percent had more than 36 years old. It means the respondents who work in startup companies are mostly generation $\mathrm{Y}$ or millennials (aged 24 - 36 years), and then generation $\mathrm{Z}$ (aged less than 24 years). 
The majority of the respondent's educational backgrounds had a bachelor's degree (69.75 percent), 13.45 percent had a senior high school, 10.92 percent had a diploma (D3), and 5.88 percent had a master's degree. Hence, startup management needs to provide training and development programs for employees to improve their skills and knowledge to generate new, innovative ideas that can ultimately improve their innovation performance. This study found evidence that 7.56 percent of managerial positions come from high school and undergraduate education, and they are contract employees. Meanwhile, 21.85 percent came from the education levels ranging from high school to $\mathrm{S} 2$ and had status as permanent employees. It means that occupying managerial positions is not based on educational background or employee status.

Concerning work experience, 54.62 percent had 1-3 years, 21.85 percent had 7-11 months, 11.76 percent had less than six months, 9.24 percent had 4-6 years, and 2.52 percent had more than seven years of work experience. It means the respondents are quite familiar with the environment and their leaders.

\subsection{Measures}

Paternalistic leadership is a "fatherly" leadership style in which clear and strong authority combined care, concern, and consideration for subordinates with moral elements [21, 34]. Researchers used a twentyseven items questionnaire to measure benevolent, moral, and authoritarian leadership taken from Cheng's study [34]. The statements in the research questionnaire were translated into Indonesian to facilitate filling out the questionnaire by respondents.

As a concept of motivation, psychological empowerment referred to an individual's belief in achieving a goal [30]. The dimensions used are meaning, competence, self-determination, and impact. Researchers used twelve items questionnaire to measure empowerment, which was adapted from Spreitzer [19].

Innovative behavior is an individual behavior in generating a problem or providing new ideas, processes, procedures, solutions, and products, introducing or supporting and building support and implementing them into work, benefits individual, group, or organizational performance [9, 12, 40, 41]. Six items questionnaire adapted from Scott and Bruce's [42], and three items adapted from Dedahanov [18].

\section{RESULT AND DISCUSSION}

The descriptive analysis used in this study is the average value of respondents' answers. Average represents the most used data or centralized data. The formula used is the maximum value minus the minimum value, divided based on the number of categories [52]. This study uses a Likert scale of one to five, and the number of the selected categories is three so that the class ranges are as follows (Table 1):
Table 1. Mean categorization

\begin{tabular}{cc}
\hline Mean & Category \\
\hline $1.00-2.33$ & Low \\
$2.34-3.67$ & Moderate \\
$3.68-5.00$ & High \\
\hline
\end{tabular}

Table 2 demonstrates the standard deviation and the mean of each variable. Benevolent leadership, moral leadership, authoritarian leadership, psychological empowerment, and innovative behavior has a mean value of $3.45,3.16,3.12,4.00$, and 3.79, respectively.

A mean score of benevolent, moral, and authoritarian leadership are moderate; means most of the respondents perceived their leaders treated them well and reasonably enough. Moreover, a mean score of psychological empowerment and innovative behavior are high; people tend to view themselves positively (Table 2 ).

The model represents the conceptual framework in Figure 1, a statistical model with three independent variables (benevolent, moral, and authoritarian leadership), psychological empowerment as a mediator, and innovative behavior as a dependent variable.

Table 2. Descriptive statistics (mean, standard deviations, and mean categorization)

\begin{tabular}{|c|c|c|c|}
\hline Variables & Mean & SD & Category \\
\hline $\begin{array}{l}\text { 1. Benevolent } \\
\text { Leadership }\end{array}$ & 3.45 & 0.77 & Moderate \\
\hline $\begin{array}{l}\text { 2. Moral } \\
\text { Leadership }\end{array}$ & 3.16 & 0.76 & Moderate \\
\hline $\begin{array}{l}\text { 3. Authoritarian } \\
\text { leadership }\end{array}$ & 3.12 & 0.67 & Moderate \\
\hline $\begin{array}{l}\text { 4. Psychological } \\
\text { Empowerment }\end{array}$ & 4.00 & 0.49 & High \\
\hline $\begin{array}{l}\text { 5. Innovative } \\
\text { Behavior }\end{array}$ & 3.79 & 0.57 & High \\
\hline
\end{tabular}

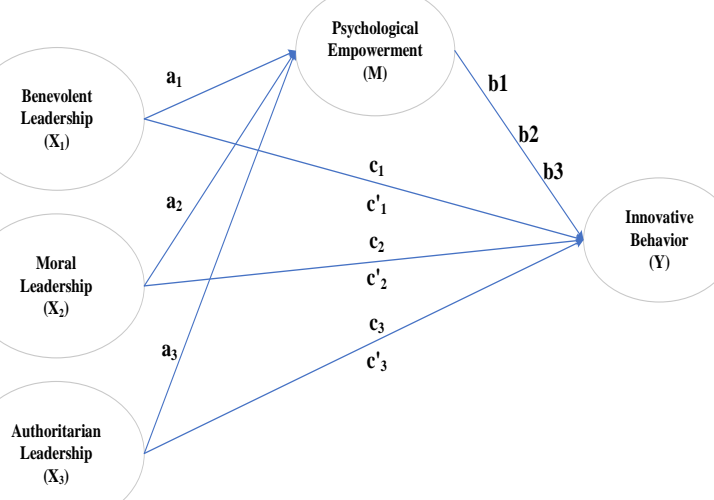

Figure 1 Statistical model 
Researchers used Hayes process method to assess the proposed hypotheses and evaluate psychological empowerment's mediating role. Researchers performed a bootstrapping test by extracting 5000 bootstrapped samples from the dataset based on random sampling with replacement, and 95 percent bias-corrected confidence intervals (CI) were calculated. The mediation is assumed when the CI of an indirect effect does not contain zero (0).

From Table 2, it was found that benevolent leadership has a positive and significant $(\beta=0.240, p$ $<0.05), \mathrm{H} 1$ is supported. Authoritarian leadership has a positive and significant $(\beta=0.195, p<0.05)$ effect on psychological empowerment, H3 is not supported. Moreover, psychological empowerment has a positive and significant $(\beta=0.646, p<0.05)$ effect on innovative behavior, $\mathrm{H} 4$ is supported. However, findings indicate that moral leadership has a positive but not significant $(\beta=0.053, p>0.05)$ effect on psychological empowerment. Thus, H2 is not supported.

Moreover, the results of Table 2 shows that psychological empowerment perfectly mediates the effect of benevolent leadership $(\beta=0.147, p<0.05$, $\mathrm{CI}_{0.95}$ 0.065, 0.236), and authoritarian leadership $(\beta=$
0.123, $p<0.05, \mathrm{CI}_{0.95} 0.002,0.238$ ) on innovative behavior. Hence, H5 and H7 are supported. However, psychological empowerment does not explain the effect of moral leadership $\left(\beta=0.034, p>0.05 ; \mathrm{CI}_{0.95}\right.$ $0.103,0.181$ ) on innovative behavior, H6 is not supported.

This study's main purpose was to investigate the effect of benevolent, moral, authoritarian leadership on psychological empowerment, the effect of psychological empowerment on innovative behavior, and the mediating role of psychological empowerment on the effect of paternalistic leadership on innovative behavior. In general, the results provided support for our hypotheses:

First, researchers found that benevolent leadership has a positive and significant effect on psychological empowerment. When leaders care deeply about employees who have worked with them for a long time, fulfill their employees' demands, it makes employees feel empowered. Besides, when leaders provide support when employees have difficulty and devote all their energy to caring for their employees, they feel empowered. This finding is in line with previous study [18] that benevolent leadership is significantly related with empowerment.

Table 2. Hierarchical linear modelling and mediating role analysis

\begin{tabular}{|c|c|c|c|c|c|c|c|c|c|c|}
\hline \multirow{2}{*}{ Path } & \multicolumn{5}{|c|}{$\begin{array}{c}\text { Psychological Empowerment } \\
\text { (M) }\end{array}$} & & \multicolumn{4}{|c|}{$\begin{array}{c}\text { Innovative Behavior } \\
(\mathbf{Y})\end{array}$} \\
\hline & & $\boldsymbol{\beta}$ & $t$ value & $p$ value & $\begin{array}{c}95 \% \text { CI } \\
\text { (LLCI, ULCI) }\end{array}$ & & $\boldsymbol{\beta}$ & $t$ value & $p$ value & $\begin{array}{c}95 \% \text { CI } \\
\text { (LLCI, ULCI) }\end{array}$ \\
\hline $\begin{array}{l}\text { Benevolent } \\
\text { Leadership } \\
\left(\mathrm{X}_{1}\right)\end{array}$ & $a_{1}$ & 0.240 & 4.040 & 0.0001 & $0.122,0.357$ & $\begin{array}{l}\mathrm{c}_{1}^{\prime} \\
\mathrm{b}_{1} \\
\mathrm{c}_{1}\end{array}$ & $\begin{array}{l}0.069 \\
0.612 \\
0.216\end{array}$ & $\begin{array}{c}1.7316 \\
10.479 \\
4.148\end{array}$ & $\begin{array}{c}0.086 \\
0.000 \\
0.0001\end{array}$ & $\begin{array}{c}-0.010,0.149 \\
0.496,0.728 \\
0.113,0.319\end{array}$ \\
\hline $\begin{array}{l}\text { Moral } \\
\text { Leadership } \\
\left(\mathbf{X}_{2}\right) \\
\end{array}$ & $\mathrm{a}_{2}$ & 0.053 & 0.520 & 0.604 & $-0.148,0.254$ & $\begin{array}{l}c_{2}^{\prime} \\
b_{2} \\
c_{2}\end{array}$ & $\begin{array}{l}0.028 \\
0.646 \\
0.062 \\
\end{array}$ & $\begin{array}{c}0.457 \\
11.658 \\
0.693 \\
\end{array}$ & $\begin{array}{l}0.649 \\
0.000 \\
0.490 \\
\end{array}$ & $\begin{array}{c}-0.093,0.148 \\
0.536,0.756 \\
-0.115,0.239\end{array}$ \\
\hline $\begin{array}{l}\text { Authoritarian } \\
\text { Leadership } \\
\left(\mathbf{X}_{3}\right)\end{array}$ & $a_{3}$ & 0.195 & 2.221 & 0.028 & $0.021,0.369$ & $\begin{array}{l}c_{3}^{\prime} \\
b_{3} \\
c_{3}\end{array}$ & $\begin{array}{l}0.070 \\
0.633 \\
0.193\end{array}$ & $\begin{array}{c}1.283 \\
11.267 \\
2.515\end{array}$ & $\begin{array}{l}0.202 \\
0.000 \\
0.013\end{array}$ & $\begin{array}{c}-0.038,0.178 \\
0.522,0.744 \\
0.410,0.345\end{array}$ \\
\hline
\end{tabular}

Note: $n=119, p<0.05, \mathrm{a}=\mathrm{X}$ on $\mathrm{M}, \mathrm{c}^{\prime}=\mathrm{X}$ on $\mathrm{Y}, \mathrm{b}=\mathrm{M}$ on $\mathrm{Y}$, indirect effect of $\mathrm{X}$ on $\mathrm{Y}=\mathrm{a} * \mathrm{~b}$, $\mathrm{c}($ total effect $)=\mathrm{a}+(\mathrm{a} * \mathrm{~b}), \beta=$ standardized coefficient

Second, researchers found that moral leadership has no significant effect on psychological empowerment. When leaders take advantage of the achievements and contributions made by their employees, employees feel not empowered. This finding is not in line with previous study [18] that reported a positive and significant relationship between moral leadership and empowerment.

Third, researchers found that authoritarian leadership has a positive and significant effect on psychological empowerment. When leaders emphasize that team must have the best performance in the company, implement strict discipline on their employees, determine all company decisions whether they are important or not, they feel empowered. This finding is not in line with previous study [18] that reported a negative relationship between authoritarian leadership and psychological empowerment.

Fourth, researchers found that psychological empowerment has a positive and significant effect on innovative behavior. When employees have autonomy, freedom and feel that their work means something to themselves and impacts the unit or company, they are more likely to generate and promote new ideas, ultimately resulting in higher quality work products and services. This finding is in line with previous study [18, 53] which found evidence that there is a positive relationship between empowerment and innovative behavior. 
Fifth, researchers found that psychological empowerment perfectly mediates benevolent and authoritarian leadership on innovative behavior, but not for moral leadership. People might claim leaders tend to be too focused on moral behavior rather than focusing on achieving innovation for the company's benefit. Under benevolent and authoritarian leaders, employees feel comfortable and don't hesitate to discuss with them.

Researchers also explore the perceived support from leaders so that employees are more innovative in work units. Most of them answer that the leader gave them motivation, given facilities supporting their work, freedom, and authority in determining steps and strategies in completing work, autonomy in using tools or equipment, and freedom to express ideas and opinions. The leaders also gave them time and participated in brainstorming.

The leader's support makes employees motivated, unified, confident, enthusiastic, and happy at work, more excited about learning, more focused, and concentrated and can express themselves more. They also feel the work's speed increases; work becomes more organized, work becomes more effective, and becomes more critical and innovative; the work environment becomes positive and less monotonous.

Also, leaders encourage employees to use their initiatives, provide advice for unit and company development, and actively generate innovative behavior. The key to employees' innovative behavior is how employees generate innovative ideas, communicate ideas, and then implement them in companies.

With the leader's support and empowerment, employees can generate new ideas through risk analysis, market analysis, customer complaints analysis, reading articles, seeing trends, brainstorming, problem identification, analyzing problems, finding solutions, and conducting research. After generating ideas, employees communicate the ideas with the team and leaders during meetings or sharing sessions.

After being approved, the next step in implementing the idea is to make action plans, discuss with related teams and divisions, listen to their perspectives, create prototypes, conduct trial and error, make improvement process designs, and implement a sprint system in work productivity and evaluate it.

To realize innovative behavior within the company, leaders must create a positive work environment for their employees, pay attention to employees and help them overcome difficulties in work and life so that employees feel comfortable, focused on work and improve company performance.

\section{CONCLUSION}

This study investigated the mediating role of psychological empowerment on the effect of paternalistic leadership, such as benevolent, moral, and authoritarian on innovative behavior. More specifically, researchers extended the literature by providing empirical evidence about the mediating role of empowerment in the effect of benevolent and authoritarian leadership on innovative behavior. Researchers' findings that psychological empowerment does not explain the effect of moral leadership and innovative behavior.

This study provides recommendations to leaders and the organization's management in formulating $\mathrm{HR}$ management practices through leadership style, creating a positive work environment that affects employee innovative behavior through empowerment. So, it can improve the company's innovation performance.

This study has several limitations. The number of samples in this study is minimal compared to the number of startup companies in Indonesia. The COVID-19 pandemic has made several startup companies temporarily suspend research activities by outside parties. It makes researchers are challenging to get data. This study also used only self-reported data; therefore, researchers suggest future research using direct employee-supervisor when conducting the survey.

\section{AUTHORS' CONTRIBUTIONS}

Both Author 1 and Author 2 designed the conceptual model, wrote a literature review, collected the survey, and interpreted the survey results together. Author 2 encouraged Author 1 to investigate a specific aspect and supervised the findings of this work.

\section{ACKNOWLEDGMENTS}

This study was supported by Saintek Scholarship - Ministry of Research and Technology, Republic of Indonesia.

\section{REFERENCES}

[1] Y. Li, Y. Song, J. Wang, C. Li, "Intellectual Capital, Knowledge Sharing, and Innovation Performance: Evidence from The Chinese Construction Industry", Sustainability 11. DOI: https://doi.org/10.3390 / su11092713

[2] G. J. Groenewegen, F. de. Langen, "Critical Success Factors of the Survival of Start-ups with A Radical Innovation", Journal of Applied Economics and Business Research 2(3) 155171.2012

[3] B. Kim, H. Kim, Y. Jeon, "Critical Success Factors of a Design Startup Business", Sustainability 10 . DOI: https://doi.org/10.3390/su10092981. 2018

[4] J. Okrah, A. Nepp, E. Agbozo, "Exploring The Factors of Startup Success and Growth", The Business and Management Review 9(3). 2018.

[5] A. Svobodová, P. Koudelková, "Collective Intelligence and Knowledge Management as A Tool for Innovations", Economics and Management 16. 2011.

[6] J.P.J. de Jong, D. Den. Hartog, "Measuring Innovative Work Behaviour", Creativity and Innovation Management, 19(1) (2010) 23-36. DOI: 8691.2010.00547.x https://doi.org/10.1111/j.1467- 
[7] H.T. Hurt, K. Joseph, "Scales for The Measurement of Innovativeness", Human Communication Research, 4(1) 58-65. DOI: https:// doi.org/10.1111/j.1468-2958. tb00597.x. 1977.

[8] M.A. West, "A Measure of Role Innovation at Work", British Journal of Social Psychology 26(1) 83-85. DOI: https://doi.org/10.1111/j.20448309.1987.tb00764.x. 1987

[9] O. Janssen, "Job Demands, Perceptions of eVort-Reward Fairness and Innovative Work Behaviour", Journal of Occupational and Organizational Psychology 73 287-302. DOI: https://doi.org/10.1348/096317900167038. 2000

[10] D. Jiménez-Jiménez, R. Sanz-Valle, "Innovation, Organizational Learning, and Performance", Journal of Business Research, 64 408-417. DOI: https://doi.org/10.1016/j.jbusres.2010.09.010. 2011

[11] T.T. Kim, G. Lee, "Hospitality Employee Knowledge-Sharing Behaviors in The Relationship Between Goal Orientations and Service Innovative Behavior", International Journal of Hospitality Management 34 324-337. DOI: https://doi.org/10.1016/j.ijhm.2013.04.009. 2013

[12] J.P.J. de Jong, D. Den. Hartog, "How Leaders Influence Employees' Innovative Behaviour", European Journal of Innovation Management 10(1) 41-64. DOI: https://doi.org/10.1108/ 14601060710720546. 2007

[13] Y. Bai, L. Lin, P.P. Li, "How to Enable Employee Creativity in A Team Context: A Cross-Level Mediating Process of Transformational Leadership", Journal of Business Research 69(9) 3240-3250. DOI: https://doi.org/10.1016/j. jbusres. 2016.02.025. 2016

[14] J. Gu, G. Wang, H. Liu, D. Song, C. He, "Linking Authoritarian Leadership to Employee Creativity", Chinese Management Studies 12(2) 384-406. DOI: https://doi.org/ 10.1108/CMS-102017-0294. 2018

[15] A.Y. Zhang, A.S. Tsui, D.X. Wang, "Leadership Behaviors and Group Creativity in Chinese Organizations: The Role of Group Processes", The Leadership Quarterly 22 851-862. DOI: https://doi.org/ 10.1016/j.leaqua.2011. 07.007. 2011

[16] Y. Wang, C. Tang, S.E. Naumann, Y. Wang, "Paternalistic Leadership and Employee Creativity: A Mediated Moderation Model", Journal of Management and Organization 25(1) 1-20. DOI: https://doi.org/10.1017/ jmo.2017.8. 2017

[17] A.N. Pieterse, D. Van. Knippenberg, M. Schippers, D. Stam, "Transformational and Transactional Leadership and Innovative Behavior: The Moderating Role of Psychological Empowerment", Journal of Organizational Behavior 31(4) 609-623. DOI: https://doi.org/10.1002/ job.650. 2010
[18] A.T. Dedahanov, F. Bozorov, S. Sung, "Paternalistic Leadership and Innovative Behavior: Psychological Empowerment as A Mediator", Sustainability 11 (2019). DOI: https://doi.org/ 10.3390/ su11061770. 2019

[19] G.M. Spreitzer, "Psychological Empowerment in The Workplace: Dimensions, Measurement, and Validation", Academy of Management Journal 38(5) 1442-1465. DOI: https:// doi.org/ 10.5465/256865. 1995

[20] K.W. Thomas, B.A. Velthouse, "Cognitive Elements of Empowerment: An interpretive Model of Intrinsic Task Motivation", Academy of Management Review 15(4) 666-681. DOI: https://doi.org/ 10.5465/amr.1990. 4310926. 1990

[21] J.L. Farh, B.S. Cheng, A Cultural Analysis of Paternalistic Leadership in Chinese Organizations. In Management and Organizations in the Chinese Context, Palgrave Macmillan, pp. 84-127. 2000

[22] C. Li, K. Wu, D.E. Johnson, M. Wu, "Moral Leadership and Psychological Empowerment in China", Journal of Managerial Psychology, 27(1) 90-108. 2012

[23] A. Wang, B. Cheng, "When Does Benevolent Leadership Lead to Creativity? The Moderating Role of Creative Role Identity and Job Autonomy", Journal of Organizational Behavior, 31(1) 106-121. DOI: https://doi.org/10.1002/job.634. 2010

[24] P. Wang, S. Wang, What role does the authoritarian leadership and benevolent leadership play in the relationship between voice behavior and innovative behavior?, in: Proceedings of the $3^{\text {rd }}$ International Conference on Education, Sports, Arts, and Management Engineering (ICESAME), Atlantis Press, China, pp. 282-286. 2018.

[25] A.T. Dedahanov, D.H. Lee, J. Rhee, J. Yoon, "Entrepreneur's Paternalistic Leadership Style and Creativity: The Mediating Role of Employee Voice", Management Decision 54(9) 2310-2324. 2016

[26] S. Aryee, Z.X. Chen, L-Y. Sun, Y.A. Debrah, "Antecedents and Outcomes of Abusive Supervision: Test of A Trickle-Down Model", Journal of Applied Psychology 92(1) 191-201. DOI: https://doi.org/10.1037/0021-9010. 92. 1. 191. 2007

[27] W. Lei, S. Kan, "Paternalistic Leadership and Job Involvement: The Mediating Role of Psychological Empowerment", Studies of Psychology and Behavior 8(2) 88-93. 2010

[28] L. Gumusluoglu, Z. Karakitapoglu-Aygün, T.A. Scandura, "A Multilevel Examination of Benevolent Leadership and Innovative Behavior in R\&D Contexts: A Social Identity Approach”, Journal of Leadership \& Organizational Studies, 24(4) 479-493. DOI: https://doi.org/10.1177/1548051817705810. 2017 
[29] Q. Gu, T.L-P. Tang, W. Jiang, "Does Moral Leadership Enhance Employee Creativity? Employee Identification with Leader and Leader-Member Exchange (LMX) in The Chinese Context", Journal of Business Ethics 126 513-529. DOI: https://doi.org/10.1007/s10551-013-1967-9. 2015

[30] J.A. Conger, R.N. Kanungo, "The Empowerment Process: Integrating Theory and Practice", Academy of Management Review 13(3) 471482. DOI: https://doi.org/10.2307/258093. 1988.

[31] M.A. Zimmerman, Empowerment Theory. In J. Rappaport \& E. Seidman (Eds.), Handbook of Community Psychology, Springer, pp. 43-63. 2000.

[32] S.T. Menon, "Employee Empowerment: An Integrative Psychological Approach", Applied Psychology 50(1) 153-180. 2001

[33] B.E. Ashforth, "The Experience of Powerlessness in Organizations", Organizational Behavior and Human Decision Processes 43(2) 207-242. DOI: https://doi.org/10.1016/07495978(89)90051-4. 1989

[34] B.S. Cheng, L.F. Chou, T.Y. Wu, M.P. Huang, J.L. Farh, "Paternalistic Leadership and Subordinate Responses: Establishing A Leadership Model in Chinese Organizations. Asian Journal of Psychology, 7(1) (2004) 89117. https://doi.org/10.1111/j.1467-839X. 2004.00137.x. 2004

[35] D.W. Irawanto, P.L. Ramsey, D.C, Tweed, "Exploring Paternalistic Leadership and Its Application to The Indonesian Public Sector", The International Journal of Leadership in Public Services 8(1) 4-20. 2012.

[36] A.S. Tsui, J.L. Farh, "Where Guanxi Matters: Relational Demography and Guanxi in The Chinese Context", Work and Occupations 24(1) 56-79.

DOI: https://doi.org/10.1177/0730888497024001005. 1997.

[37] C.P. Niu, A.C. Wang, B.S. Cheng, "Effectiveness of A Moral and Benevolent Leader: Probing The Interactions of The Dimensions of Paternalistic Leadership", Asian Journal of Social Psychology 12(1) 32-39. DOI: https://doi.org/10.1111/j.1467839X.2008.01267.x. 2009.

[38] X.P. Chen, M.B. Eberly, T.J. Chiang, J.L. Farh, B.S. Cheng, "Affective Trust in Chinese Leaders: Linking Paternalistic Leadership to Employee Performance", Journal of Management 40(3) 796-819. DOI: https://doi.org/10. 1177/0149206311410604. 2014

[39] R.C. Ford, M.D. Fottler, "Empowerment: A Matter of Degree", Academy of Management Executive 9(3) 21-29. DOI: https://doi.org/10.5465/ame.1995.9509210269. 1995

[40] M. Lukes, U. Stephan, "Measuring Employee Innovation: A Review of Existing Scales and The Development of The Innovative Behavior and Innovation Support Inventories Across Cultures",
International Journal of Entrepreneurial Behavior \& Research 23(1)136-158. DOI: https://doi.org/ 10.1108/IJEBR-11-2015-0262. 2017.

[41] A. Carmeli, R. Meitar, J. Weisberg, "SelfLeadership Skills and Innovative Behavior at Work", International Journal of Manpower 27(1) 75-90. DOI: https://doi.org/ 10.1108/ 01437720610652853. 2006

[42] S.G. Scott, R.A. Bruce, "Determinants of Innovative Behavior: A Path Model of Individual Innovation in The Workplace", Academy of Management Journal 37(3) 580-607. DOI: https://doi.org/ 10.5465/256701. 1994.

[43] R.W. Woodman, J.E. Sawyer, R.W. Griffin, "Toward A Theory of Organizational Creativity", The Academy of Management Review 18(2) 293-321. DOI: https://doi.org/ 10.5465/amr.1993. 3997517.1993.

[44] N. Ramamoorthy, P.C. Flood, T. Slattery, R. Sardessai, "Determinants of Innovative Work Behaviour: Development and Test of An Integrated Model", Creativity and Innovation Management, 14(2) 142-150. DOI: https://doi.org/10.1111/j.1467-8691. 2005.00334.x. 2005.

[45] S.De. Spiegelaere, G.Van. Gyes, G.Van. Hootegem, "Not All Autonomy is The Same. Different Dimensions of Job Autonomy and Their Relation to Work Engagement \& Innovative Work Behavior", Human Factors and Ergonomics in Manufacturing \& Service Industries 26(4) 1-13. https://doi.org/ 10.1002/hfm.20666. 2016.

[46] J. Zhu, J. Yao, L. Zhang, "Linking Empowering Leadership to Innovative Behavior in Professional Learning Communities: The Role of Psychological Empowerment and Team Psychological Safety", Asia Pacifc Education Review, 20(4) 657-671. DOI: https:// doi. org/10.1007/s12564-019-09584-2. 2019

[47] R.E. Ripley, M.J. Ripley, "Empowerment, The Cornerstone of Quality: Empowering Management in Innovative Organizations in The 1990s", Management Decision 30(4) 20-43. DOI: https://doi.org/10.1108/00251749210014743. 1992

[48] A.T. Dedahanov, C. Kim, J. Rhee, "Centralization and Communication Opportunities as Predictors of Acquiescent or Prosocial Silence", Social Behavior and Personality 43(3) 481-492. DOI: https://doi.org/ 10.2224/ sbp. 2015. 43.3.481. 2015.

[49] M. Singh, A. Sarkar, "Dimensions, Outcomes and Mediating Roles of Empowerment", Management and Labour Studies 38(4) 315-333. DOI: https://doi.org/10.1177/0258042X13513130. 2013.

[50] J. Bormans, M. Privitera, E. Bogen, T. Cooney, European Startup Monitor, European Startup Network and European Commission, 2019.

[51] V. Mulas, K. Qian, J. Garza, S. Henry, M. 
Lerner, K. Robinson, M. Raad, Tech Startup Ecosystem in West Bank and Gaza, World Bank, 2018.

[52] S. Jaggia, A. Kelly, Business Statistics: Communicating With Numbers (3rd ed.), McGraw-Hill Education, 2013.

[53] S.E. Seibert, G. Wang, S.H. Courtright, "Antecedents and Consequences of Psychological and Team Empowerment in
Organizations: A Meta-Analytic Review", Journal of Applied Psychology, 96(5) 981-1003. DOI: https:// doi.org/ 10.1037/a0022676. 2011

[54] A.S. Tsui, H. Wang, L. Zang, K. Xin, P.P. Fu, "Let A Thousand Flowers Bloom: Variation of Leadership Styles Among Chinese CEOs", Organizational Dynamics 33(1) 5-20. DOI: https://doi.org/10.1016/j.orgdyn.2003.11.002. 2004. 